\title{
Barbys humanas y maternidades gore en el parvulario del infierno: la narrativa ominosa de Diana Beláustegui
}

\section{acceso $\odot$ abierto}

Para citaciones:

Sosa, C. (2020). Barbys humanas y maternidades gore en el parvulario del infierno: la narrativa ominosa de Diana Beláustegui. Visitas al Patio, 14(2), 173-176. DOI: 10.32997/RVP-vol.14-num.2-20202787

Editor: Silvia Valero. Universidad de Cartagena-Colombia.

Copyright: (C) 2020. Sosa, C. Este es un artículo de acceso abierto, distribuido bajo los términos de la licencia https://creativecommons.org/licenses/by-nc$\underline{\mathrm{sa} / 4.0 /}$ la cual permite el uso $\mathrm{sin}$ restricciones, distribución y reproducción en cualquier medio, siempre y cuando el original, el autor y la fuente sean acreditados.

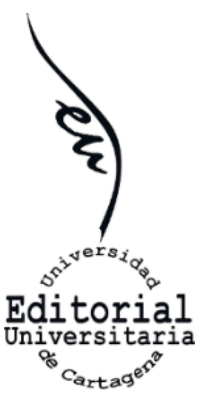

Carlos Hernán Sosa ${ }^{1}$

Universidad Nacional de Salta
Como muchos otros representantes de la producción narrativa reciente en Argentina, gestada desde diferentes centros culturales regionales, fuera de la dinámica de las grandes ciudades metropolitanas del país, Diana Beláustegui ha sostenido una intensa tarea de autogestión alternativa y ha participado de formas de difusión de la literatura, principalmente, por los carriles que facilita la web, desde la ciudad de Santiago del Estero en el noroeste del país, lugar donde reside y desarrolla sus actividades. La incesante tarea emprendida desde las redes y en los distintos espacios polifuncionales de promoción y circulación artística (ferias de editoriales alternativas, festivales poéticos y otros eventos) por los cuales circula la literatura actualmente en Argentina, ha servido de escenario para dar a conocer una producción innovadora que deja trazos distintivos en el horizonte del contexto de producción regional del noroeste argentino y que, además, tracciona interesantes redes con las producciones contemporáneas de otros espacios culturales del país, como Buenos Aires y Córdoba. En su último libro publicado, Cuentos inadaptados. La era de la destrucción, se incorporó "Compañeros se juego", muestra acotada que aquí se ofrece y que, sin embargo, logra una aproximación neta a las variaciones de potentes sentidos que nos propone la narrativa de Beláustegui.

Una de las obsesiones temáticas de la autora, un auténtico itinerario topicalizado en su narrativa, es el cuestionamiento a la representación falocéntrica que sobre las mujeres reiteran los mandatos sociales preestablecidos y que, en sintonizada complicidad, se reproducen desde los estándares tipificados por las industrias culturales. El universo literario de Beláustegui aparece poblado por la discusión de los guiños consumistas que van incorporando estos lugares periferizados para la vida de las mujeres, con sus roles de género prefigurados, las tareas ad hoc y la configuración general de toda una cosmovisión excluyente.

De esta manera, un conjunto de relatos de la autora va urdiendo los lugares sociales estigmatizados sobre las mujeres - la prostituta en "Barby Two", la mujer que aborta en "Hambre" y "Compañeros de juego"-; y también la victimización que se advierte en la tematización del cautiverio y abuso de niños en "La niña morena" y "Septiembre", la agresión física de las parejas masculinas en "Barby" y "Apariencias" y la persecución que sufren en la calle por los varones abusadores en "Esa noche".

${ }^{1}$ Doctor en Letras por la Universidad Nacional de Tucumán, Argentina. Profesor asociado regular en la carrera de Letras, en la Facultad de Humanidades de la Universidad Nacional de Salta. Investigador asistente del CONICET, donde actualmente investiga las principales líneas de la narrativa reciente en el noroeste argentino. chersosa@hotmail.com 
Una estrategia elegida para aproximarse a estos asuntos, desde la enunciación narrativa, es la apelación a los imaginarios populares (desde las historias de fantasmas hasta las recetas abortivas con yuyos, cada uno con su justa medida de horror y cinismo social). La insistencia en la incorporación del imaginario infantil, como reducto oscuro donde se catalizan procesos sociales, hace empalmar muchas de las historias de Beláustegui con una línea fuerte de la narrativa argentina, abierta a mediados de siglo XX por Silvina Ocampo y retomada también por otras recientes herederas de Ocampo, como las escritoras argentinas Samanta Schweblin, Mariana Enriquez y Agustina Bazterrica, todas ellas contemporáneas de la narrativa de Beláustegui. Abunda, entonces, en los cuentos de la autora, la presencia de los miedos infantiles (cucos y aparecidos son una constante), amplificados hasta el terror más palpable; y el espacio epifánico de los juegos infantiles, que logra en "Compañeros de juego", donde también se intuye la presencia del amigo imaginario -un auténtico leitmotiv de la infancia-, una de sus instancias más revulsivas. En este sentido, probablemente sea con la escritura de Schweblin con la que pueden observarse mayores ecos y resonancias de la narrativa de Beláustegui. Al menos, una novela como Distancia de rescate (2014), constreñida al develamiento de lo asfixiante y alienador de la experiencia de la maternidad, o el cuento "Conservas", incluido en Pájaros en la boca (2008), donde con una estilización paralizante se aborda la temática del aborto, invitan a explorar filiaciones que guardan mayor conciliación entre algunas zonas permeables de la obra de ambas autoras.

Por otra parte, también es el mundo del juego infantil el que escenifica la dramatización del temprano constreñimiento social de las niñas, desde la aparentemente inocua diversión con juguetes que deviene un efectivo señalamiento de roles. Con la contundencia verbal que impera en el género, uno de los microrrelatos de la autora así lo expone, sin medias tintas:

\section{"Muñecas"}

No quería dejar de jugar a las muñecas, el llamado de las hijas plásticas lo sentía con extraña exactitud en la parte inferior derecha del abdomen.

Me duele, pensaba, y sabía que ellas la necesitaban como cuando a una madre le duelen las tetas llenas de leche y sabe que su hijo succiona el aire.

Entonces dejaba lo que estaba haciendo para ir a mimar a sus sanguijuelas de mentirita.

Ya no quería cuidarlas, en ocasiones soñaba que las enterraba en el fondo de la casa.

Fue un miércoles, mientras saltaba la cuerda, cuando el dolor le recordó que sus hijas adoptivas la esperaban y desoyó el llamado, esa misma tarde le reventó el apéndice, el estallido se escuchó en toda la casa, hizo pum, crash, y otros ruiditos como de succión.

La niña se miraba la panza mientras sus padres corrían de un lado a otro sin hacer nada.

Cuando regresó del hospital sin su apéndice, creyó que por fin descansaría de sus hijas demandantes.

La primera tarde que pudo salir a jugar estuvo un par de horas con sus amigas, hasta que sintió un tirón en su brazo izquierdo y una leve presión en el pecho.

Los "inocentes" juegos con muñecas asumen además otras fisonomías siniestras, pues tal vez no exista otro objeto asociado a la infancia que entrañe tantos matices 
oscuros como las muñecas. Se replican en Beláustegui las muñecas con aristas paradójicas que traen a primer plano el horror soterrado de estas figuras inertes; los personajes se comportan, a veces, como muñecas que, en clave inquietante, suelen aparecer monstruosas y viejas. Develan, así, la veta ominosa de estos homúnculos de juguete, miniaturas de sujetos acondroplásicos que a pesar de que nunca crecen sin embargo parecen envejecer: se decoloran, pierden el pelo, harapean sus vestiditos.

Y es que el modo en que los relatos de Beláustegui tramitan la presentación de estos temas -de gran hondura social sobre las mujeres en el mundo- prioriza, en general, las opciones más incómodas del decir. Antes que lamentarse o polemizar sobre la herida abierta, su literatura elige humillar con mayor dolor las laceraciones, para convertirlas entonces en figuraciones verbales difíciles de digerir.

Otra estrategia compositiva importante, mediante la cual temáticamente se orientan las narraciones de la escritora, actúa en el mismo sentido disruptivo. La mayoría de estos cuentos entran dentro de la categoría del fantasy, es decir, las distintas versiones que ciertas modalidades (terror, ciencia ficción, fantástico, maravilloso) adoptan desde la perspectiva crítica de Rosemary Jackson. Jackson elabora esta noción conceptual para agrupar aquellos discursos sociales, muchos de ellos vehiculizados por el arte -como la literatura y el cine-, donde se desocultan zonas reprimidas por las sociedades, en las que se repliega, pero sigue pulsando el conflicto cultural, a pesar de la domesticación homogeneizadora de discursos y prácticas que impone la vida en comunidad. Las presentaciones urticantes que los relatos de Beláustegui proponen se comportan como verdaderas instancias de exploración -y de desenmascaramiento- sobre nudos irresueltos de la conflictividad social gestada en torno a los lugares periferizados para las mujeres. Una instancia que asume sus particularidades propias, a su vez, por la perspectiva peculiar que le asigna una escritora joven desde su lugar en el mundo: una periférica ciudad del interior de un país latinoamericano, en una de las regiones de Argentina donde los índices de femicidios y muertes por abortos clandestinos ocupan las cifras más elevadas en las estadísticas oficiales.

Por todo esto, es frecuente -y en algún punto también esperable-la resolución por el camino de la violencia que asumen esos relatos, ya que parece ser imposible otro desenlace para esta discursividad literaria que expone de manera virulenta una lectura fuertemente contestaria sobre la situación de desprotección de las mujeres en el mundo actual. La utilización de los recursos hiperbólicos del cómic (recordemos las interjecciones, a lo Batman, que aparecen en "Muñecas"), del cine de terror gore (tan plásticamente recreado en "Compañeros de juegos", a partir de una suerte de versión asesina femenina de Friday the 13th) e incluso los caricaturescos contornos de la crónica roja aportan su batería de imágenes cruentas y efectivas. Entonces, no cuesta demasiado entrever, semiocultas en las imágenes trastabilladas por lo literario, distintas versiones opresoras de los feminismos: en las mujeres perseguidas que se transforman en seres monstruosos y asesinan, con alevosía inverosímil, a sus persecutores; en las grotescas prostitutas siliconadas, que se almuerzan a sus clientes ocasionales; en el desembarazo hiperbólico de las madres "asesinas" que abortan o -como nuevas Pandoras recienvenidas- terminan pariendo interminables alimañas infernales. Estas venganzas sangrientas, montadas 
como escenas de tragedia shakesperiana, cumpliendo con el requerimiento de estruendosos y coloridos derramamientos de sangre, sobreimprimen insistentes imágenes de la mujer como monstruo, enrostran otras caras no domesticadas de lo femenino, insisten en desmontar las figuras modélicas del ángel del hogar, la belleza femenina, la apoteótica maternidad. Con estas madres monstruosas que -como en "Compañeros de juego"- no abren la puerta para ir jugar, como añora la canción infantil de la rayuela, sino que demudadas en nuevas Medeas lo hacen para reprender o asesinar a los hijos; con esas entidades bestiales que se insectizan, que se animalizan, para ganar en la veta de deshumanización un afán revanchista por los horrores padecidos; con todas estas imágenes ominosas de lo femenino la narrativa de Beláustegui trama un gesto amonestador sobre las convenciones culturales contemporáneas. Lo hace gracias a la prerrogativa insobornable que la literatura detenta para reponer verdades simbólicas que sacuden los imaginarios sociales de cada momento.

Con la habilidad incontrastable que los caracteriza, los griegos pudieron cifrar en el mito de Pigmalión la modelización esclerosada, endurecida como el mismo mármol con el que el personaje esculpió su figura amada, la representación de la mujer, hecha a imagen y semejanza de las necesidades masculinas. Precisamente, lo que muchas de las escritoras integrantes de las últimas promociones de la narrativa argentina reciente proponen es la (re)invención de este relato encorsetador de las femineidades. Se esmeran en señalar las arbitrariedades de los mandatos que tan metafóricamente se implican en aquel relato aleccionador que, aunque ambientado in illo tempore, tiene vitales ramificaciones hacia nuestro presente: en las desvaloraciones extremas que logran su mayor expresión en el maltrato y asesinato de las mujeres, en las instancias de supervivencia de mujeres y niñas como ciudadanas de segundo rango, bajo legislaciones que las contemplan a medias. Las voces y los rostros de las mujeres, que la narrativa de Diana Beláustegui habilita, no obliteran esta conflictividad, por el contrario, capitalizando una de las venas más reflexivas de la literatura, nos demandan a polemizar sin eufemismos sobre la brutalidad de sepulcro blanqueado que tienen las convenciones sociales, donde se disimula el tufillo pútrido de tantas injusticias y tantos crímenes solapados. 